\title{
INVESTIGATION OF THE CHANGE OF THE SHOPPING MALL'S SPACE ORGANIZATION IN ISTANBUL
}

\author{
Guliz Ozorhona, Ilker Fatih Ozorhon $^{\mathrm{b}}$ \\ Faculty of Architecture and Design, Özyeğin University, Çekmeköy Campus \\ Nişantepe District, Orman Street, 34794 Çekmeköy, Turkey \\ E-mails: aguliz.ozorhon@ozyegin.edu.tr (correspondingauthor); bilker.ozorhon@ozyegin.edu.tr \\ Received 02 January 2014; accepted 08 April 2014
}

\begin{abstract}
Within the scope of this article shopping malls were discussed as a building type and the evolution of a building type was tried to be witnessed within a twenty-five year period by comparing the early and late examples of shopping malls in Istanbul. The change of Istanbul's shopping culture / spaces and the inclusion of shopping centers into the practice of architecture as a building type are briefly mentioned. Each of the selected malls were separately examined in terms of location, concept, space organization and other functions included, and in the fourth section both early and late examples were evaluated together in the same terms with a holistic perspective. The effect of shopping malls, the number of which constantly increases in Istanbul, on the city and its architecture is highly important. These massive bodies of buildings play a significant role in the formation and even definition of the new settlement areas of the city, and generate new areas of attraction. Due to these reasons, from location to architectural characteristic, from schedule to interior quality, they need to be designed punctiliously and with the consideration of the effects at all levels.
\end{abstract}

Keywords: shopping mall, space design, Istanbul.

Reference to this paper should be made as follows: Ozorhon, G.; Ozorhon, I. F. 2014. Investigation of the change of the shopping mall's space organization in Istanbul, Journal of Architecture and Urbanism 38(2): 120-129.

\section{Introduction}

City, according to Harvey (2013), is a place where people of all types and all classes come together and generate an ever-changing, ephemeral, but still a common experience. Shopping malls, on the other hand, are a building typology this change brings into the city. According to Birol (2005), modern shopping mall represents one of the most significant marks of the global economic system; yet it is not possible even today to state that there is a consensus concerning their design criteria or presence in the city.

Shopping malls often receive criticism in the sense that they are places of spending time, built on the image of capitalism in the city and on consumption. For instance, while Yilmaz (2002) defines shopping malls as "the landscapes of consumption", Ozkan $(2013)^{1}$ asso-

\footnotetext{
1 Quoted from the speech of Prof. Dr Suha Ozkan at Erciyes Üniversitesi Faculty of Architecture.
}

ciates these products of the global culture, i.e. shopping malls, with "prisons", stating that: "Shopping malls are not places where, for example a street musician could easily get in and perform. I consider shopping malls the same as prisons. People go to prisons by force. The only difference is, people go to shopping malls by their own will". On the other hand, it is possible to state that the old downtowns are inadequate in many aspects in terms of fulfilling the needs of metropolises such as Istanbul, and that shopping malls have turned into alternative downtowns for the citizen that wishes to shop within a certain spatial comfort and at the same time to utilize other social facilities. In other words, shopping malls present a different and comfortable new world to the users, in terms of both their architectural designs and the technology and quality material used in their construction (Güzel, Sönmez 2002). 
Leaving aside the discussion on existence mentioned above, from a typological point of view a shopping mall is a type of structure that constitutes new urban focal points by integrating many stores, one or a few department stores, a supermarket/hypermarket and areas for social activities. The present study addresses shopping malls as a spatial organization and although mentioning the related discussions, leaves the interpretation to the reader.

In the second section, the change in Istanbul's shopping culture/places and the inclusion of shopping malls in the architecture practice as a building type are briefly mentioned. Consequently, the status of shopping malls in Istanbul was set forth with a map, the locations of three early and three late shopping malls in Istanbul and the relationship between the artery roads of Istanbul and the locations of the shopping malls was exhibited on the same map, and information on the population growth in Istanbul from 1988 to 2010 were provided together with the increasing number of shopping malls within the same period. In addition, the buildings selected within the scope of the study were set forth in a table (Table 1), by considering the key elements that can describe them (description, area, construction date, program, concept). In this section also each of the selected malls were separately examined in terms of location, concept, space organization and other functions included, and in the fourth section both early and late examples were evaluated together in the same terms with a holistic perspective. In the conclusion, the findings obtained from these analyses and the suggestions for shopping malls in terms of the present of Istanbul were set forth.

In short, within the scope of this article shopping malls were discussed as a building type and the evolution of a building type was tried to be witnessed within a twenty-five year period by comparing the early and late examples of shopping malls in Istanbul. The method followed in the study is presented via the following Fig. 1.

\section{Brief history of shopping spaces in Istanbul}

Having been an important part of the urban life from past to present, shopping areas are identified with the urban identity. While sometimes the change of the city structure triggered the transformation of shopping areas, sometimes it has been the shopping malls -formed with the changing shopping culture - that played part in the transformation of the city structure (Kiliç, Aydoğan 2006). Examining the transformation of shopping areas within the course

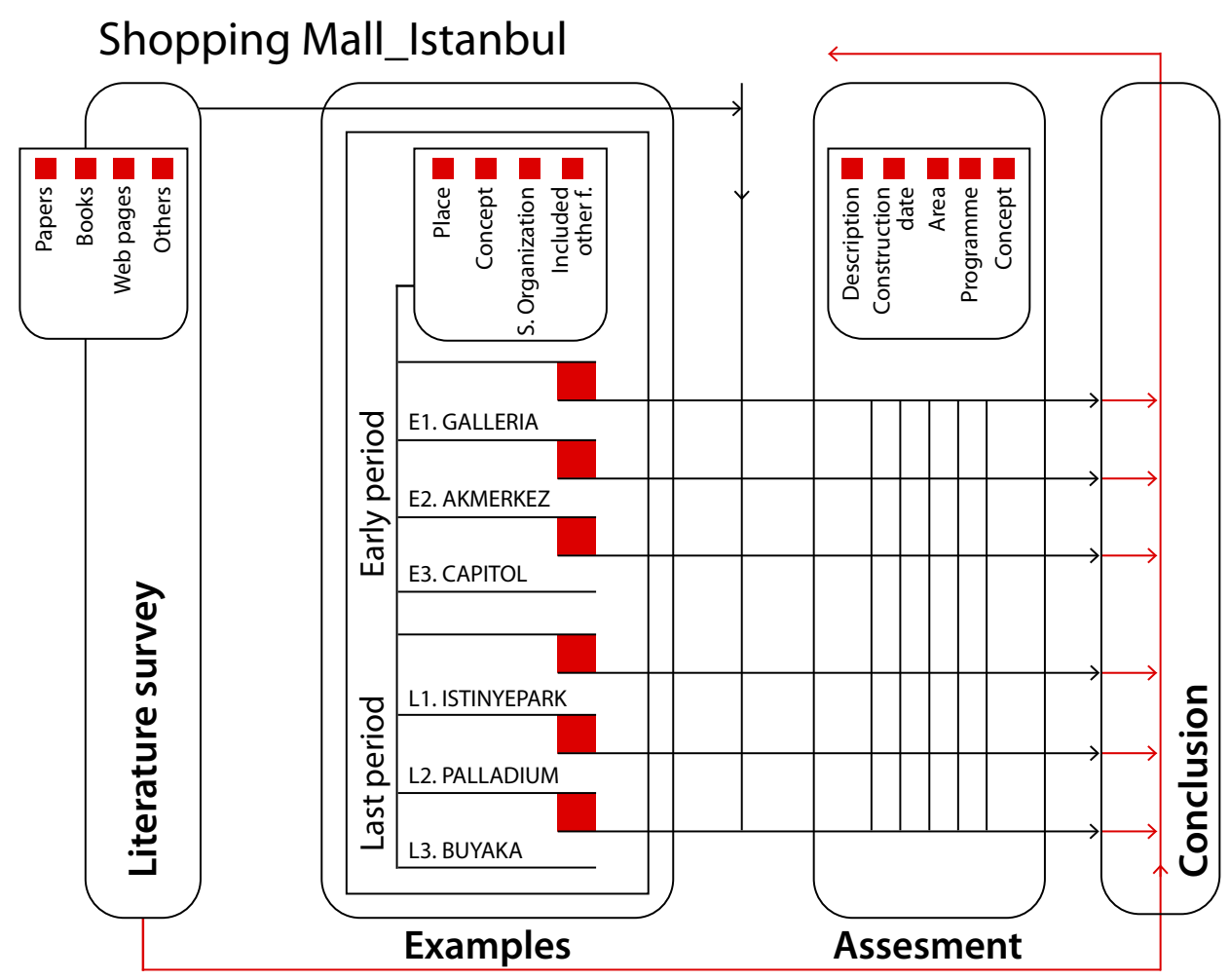

Fig. 1. The method on survey. Source: authors 
of time shows that the most typical characteristic of urban shopping areas until the 20th century was "the integration with the urban fabric". For instance, the agoras in the ancient period cities and the squares in the medieval cities were the most important shopping areas of these cities (Birol 2005). This characteristic is easily readable also for the case of Istanbul, when the shopping tradition and the places this tradition constituted are considered. Covered bazaars, inns, grand bazaars and bazaars called arasta are shopping areas that were inherited from the Ottoman State and still actively included in the urban life.

There always has been a two-way interaction between the city and the shopping places that sometimes reveal themselves as the extension of an alley, presenting several different spatial experience and surprises to the user. Dogru (1995) speaks of these structures that develop in line with the needs of the city and its dwellers, and that articulate as a part of the city as "these structures and squares directly affect the physical position of the city" (Üstün, Tutal 2008; Dogru 1995).

However, the changes in the social life in consequence of the World War 2, technological developments, evolution of cities and population growth have contributed to the emergence of the shopping malls as we know today, particularly in metropolises. With start of the sales of new types of products in new forms of shops with display windows and counters, at first stores were opened. The process that started in the 1830's continued until the 1950's in some cities and a period of draperies and agencies, which usually connoted the sales of imported goods, was witnessed. The "Bon Marche" store, which had been built by the Bortoli Brothers who settled in Istanbul in 1850 and continued its existence until the year 1926, has become the ancestor of today's supermarket and the center of shopping, style and objects. As from the second half of the 19th Century, branches of large European stores started to be established in Istanbul (Emiroglu 2002).

Migration to cities and the consequent increase in supply of housing resulted in the emergence of the remote suburbs at city perimeters. The horizontal expansion of cities made the urban population dependent on automobiles, and on top of the unresolved problems of the city life came the noise, air pollution and the insufficient parking areas. The change in the consumption patterns, coupled with the effects of the rapidly developing retail industry (Güzel, Sönmez 2002), made shopping malls -now preparing for becoming the new city centers - preferable in cities, with their characteristics of being closer to the residential areas rather than city centers and free of transportation-related problems.
Following the lead of Galleria, the very first shopping mall built in Istanbul in 1988, the number of the shopping malls in Istanbul increased rapidly. As it was also stated by Dökmeci (1995), the examples of the early stage shopping malls in Istanbul achieved high commercial success, which in turn encouraged the establishment of many new malls in the city. Arslan (2009) reports that the number of shopping malls in Turkey reached 208 in the year 2009. At that year, with a total of 71 shopping malls, Istanbul included $34 \%$ of all of the shopping malls in Turkey (Arslan 2009).

\section{Shopping malls in Istanbul}

Due to the scope and the duration of the study, it was decided to include three early period and three late period examples of shopping malls in Istanbul to the scope of the study, rather than all of them. The example buildings to be examined in details in this section are Galleria (built in 1988), Capitol (built in 1993) and Akmerkez (built in 1993) for the early stage examples and IstinyePark (built in 2007), Palladium (built in 2007) and Buyaka (built in 2012) for the late period shopping malls in Istanbul (locations of the malls are shown on the Istanbul map in Fig. 2).

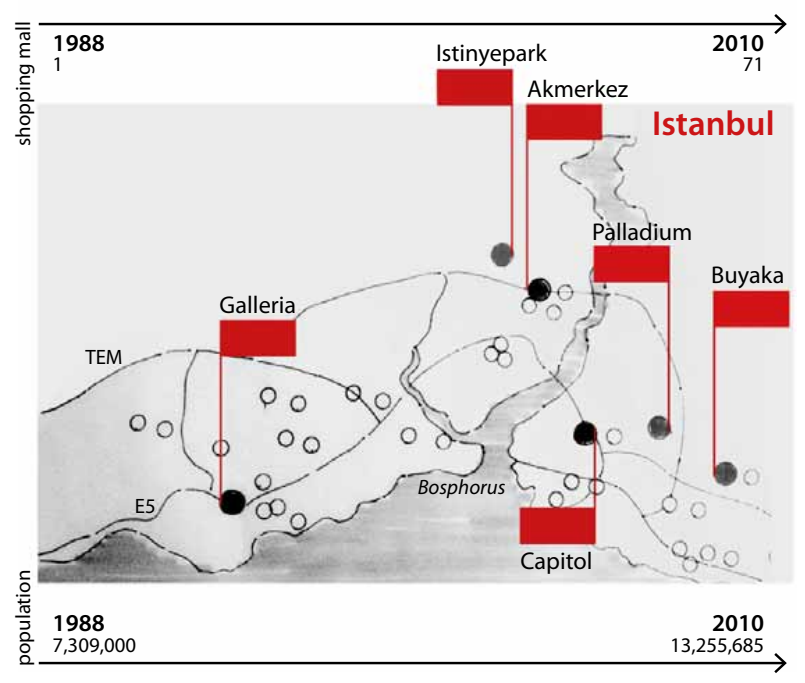

Fig. 2. "Istanbul-Shopping Mall" Collage. Source: authors

\section{Galeria}

Location. Carried out as the first shopping mall project of Istanbul and Turkey in the year 1988, Galleria was designed by Hayati Tabanlioğlu in Atakoy Tourism Center, which embodies facilities such as a marina, hotel and entertainment and congress centers (Fig. 2).

Special features. The architect of the Galleria Shopping Mall addresses the building as a modern interpretation of the traditional 'grand bazaar' (Tabanlıoğlu 1989). 


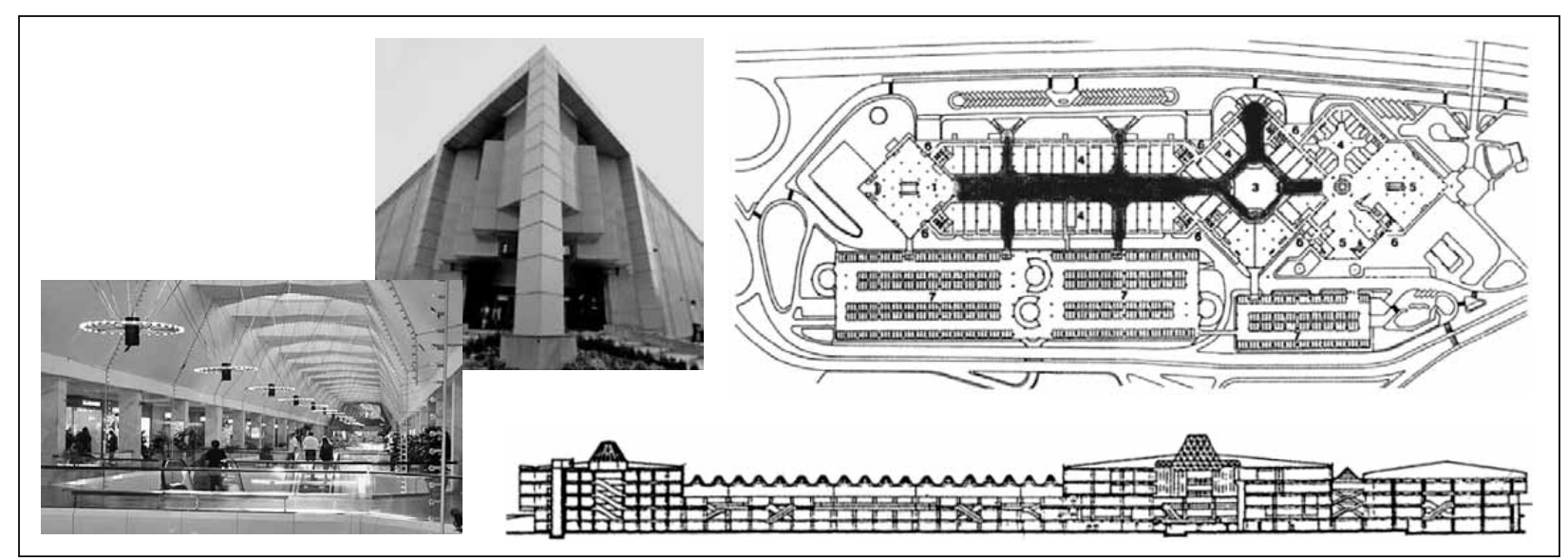

Fig. 3. Galleria Shopping Mall Plan-Exterior-Interior, Istanbul

Space organization. Includes a four-storey shop that constitutes the attraction of the mall on one end of the block and a four-storey amusement center and a food-court at the other end. Its customer circulation area receives natural light, features an atrium and galleries and connects shopping areas with the foot-court and amusement center. According to Dökmeci (1995), by means of this atrium the visitors can easily find all stores within a spatial integrity. The circulation course of Galleria Shopping Mall has a linear arrangement (Fig. 3) (Güzel, Sönmez 2002).

Other function included. The building embodies a centrally located ice-skating rink of $30 \mathrm{~m} \times 30 \mathrm{~m}$ dimensions. Galleria also features a large amusement center and offices.

\section{Akmerkez}

Location. Designed by Fatih Uran, Akmerkez was built in 1993, at the center of Istanbul, between the districts Etiler and Levent (Fig. 2).
Special features. Due to its location, the mall was built by targeting high income group.

Space organization. The four-storey tall gallery spaces at the edges of the triangle-formed building are the places where circulating visitors gather and disperse (Fig. 4). With the panoramic elevators located at these central points, vertical circulation is supported and it was tried to provide more control to the visitors on the building. Besides these three central points (cruxes), a higher level of control and a sense of spaciousness were tried to be provided to the horizontal circulation through gallery spaces, and the vertical circulation was further supported with escalators. Positioning of the escalators on top of each other strengthened accessibility within the building.

Other functions included. Other than the shopping areas in the building complex, there are three towers rising up from the three edges of the triangle form. While two of these towers are office blocks with 14 and 17 storeys, the third one serves as a 23 storey residence block.

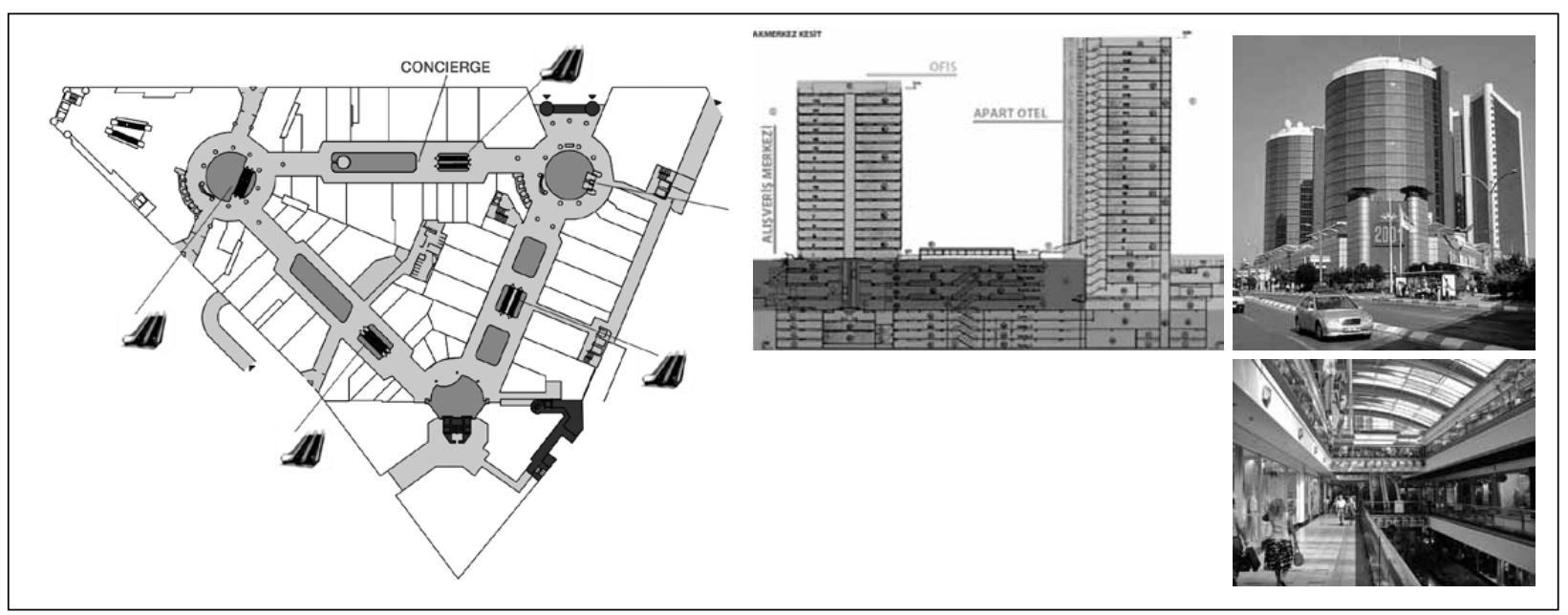

Fig. 4. Akmerkez Shopping Mall Plan-Exterior-Interior, Istanbul 


\section{Capitol}

Location. Built in the year 1993, in Altunizade as one of Istanbul's most significant residential districts, Capitol shopping mall was designed by Mutlu Cilingiroglu and Adnan Kazmanoglu as a commercial center to serve at city-scale (Fig. 2).

Special features. Sayar and Süer (2002) emphasized that two main principles had priority in the design of the building. While first of these principles is to establish an urban landmark that is integrated with and contributes to its surroundings, the second is to create a lively focus of shopping that can serve as a social activity center and to achieve the "urban center" quality of the traditional covered bazaar in a modern sense.

Space organization. Similar to Galleria, also Capitol has a linear circulation course, on the both sides of which stores are available (Fig. 5). This course was enriched with an atrium (referred to as agora by its architects) and gallery spaces in a way to ensure the continuity of perception over the storeys.

Other functions included. By including the social requirements/qualifications of the close surroundings of the building at the time of its construction, the architects identified the inclusion of movie theaters as a priority.

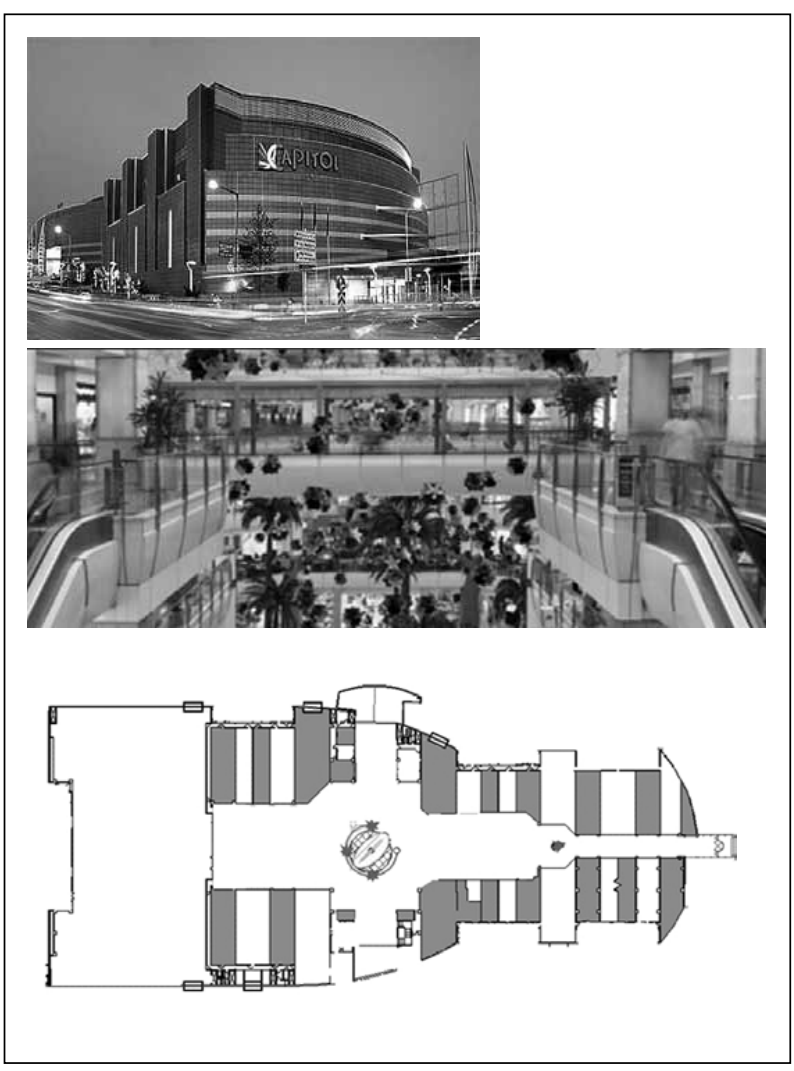

Fig. 5. Capitol Shopping Mall Plan-Exterior-Interior, Istanbul

\section{Istinyepark}

Location. IstinyePark (Fig. 2) is a shopping mall located in the Maslak quarter of the Sariyer district of Istanbul.

Special features. According to its designers, the IstinyePark project has made two contributions to shopping malls in general terms. The first is the openair section where the stores are arranged and the other one is the "market place" concept that covers specialized retailers instead of the common supermarket concept.

Space organization. The circulation axis also in IstinyePark is linear, as in the examples from the earlier stage (Fig. 6). The axis was made spacious with occasional and small squares, and an attraction area was created on the entry axis with the main gallery. The official website of the shopping mall introduces its architecture as follows: "Not only does IstinyePark introduce a progressive philosophy to shopping, its architecture also features many innovations The balanced presentation of outdoor and indoor spaces offers visitors an atmosphere that is both refreshing and comfortable. Arrangement of the stores on a single corridor makes it easy to find one's way. Activities for people of different ages or interests can be found in the activity areas that are located at different spots. The

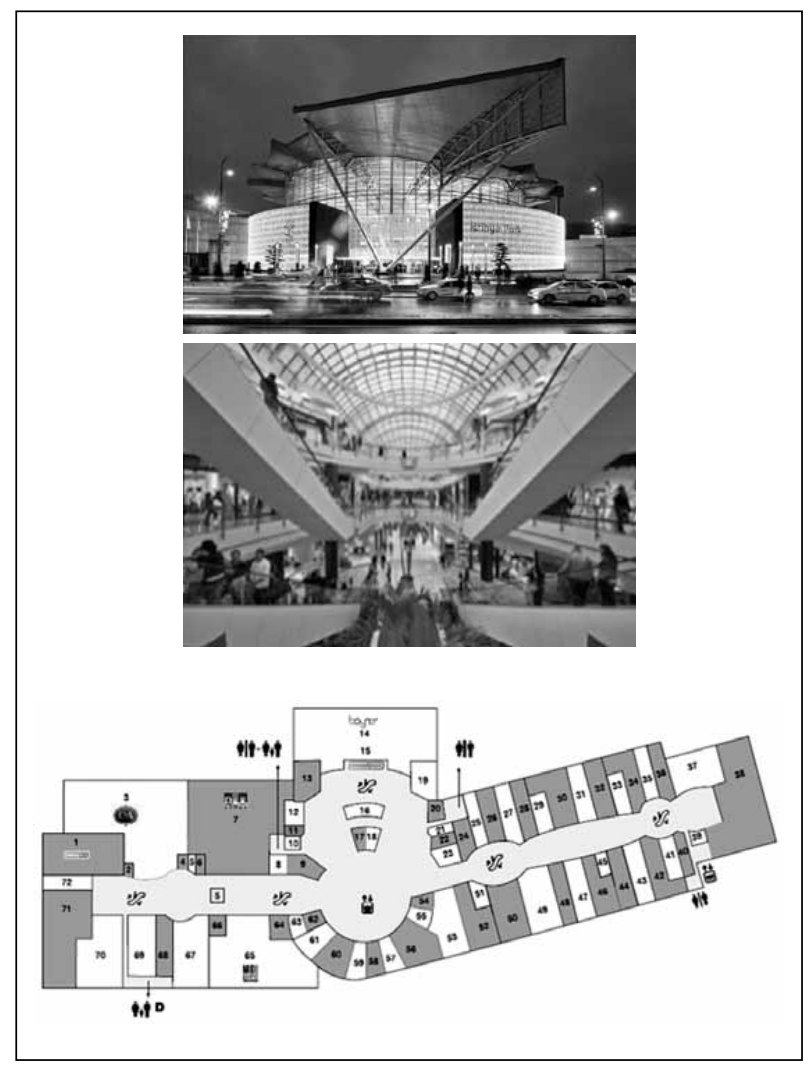

Fig. 6. Istinye park Shopping Mall Plan-Exterior-Interior, Istanbul 
delightful interaction of water and light presented in the mall was designed to provide enjoyable moments to the visitors."

Other functions included. A theatre with 12 halls, and a 3500 square meter sports and fitness center are present.

\section{Palladium}

Location. Palladium shopping mall is located in Atasehir, in the Anatolian side of Istanbul (Fig. 2).

Special features. While the building turns inwards on the face with car circulation, with its face towards the recreative green space it expends outwards. This expansion was primarily achieved with a glass sphere positioned on the central axis of the shopping mall block and that serves as a bright and spacious entrance hall. However, the sphere is not designed solely as an entrance hall but a recreational area supported by coffee shops, a colorful area of activity and a meeting point. Besides the glass sphere, the notion of expanding outwards was further strengthened with the terraces of the coffee shops on the ground level and on upper floors facing the outer garden. Surrounded by arcades as a transparent border, the garden offers the visitors a place to relax in the center of dense buildings, with the relation it forms with the coffee shops, green space, active use of the water factor, and the glass sphere (Arkiv 2013b).

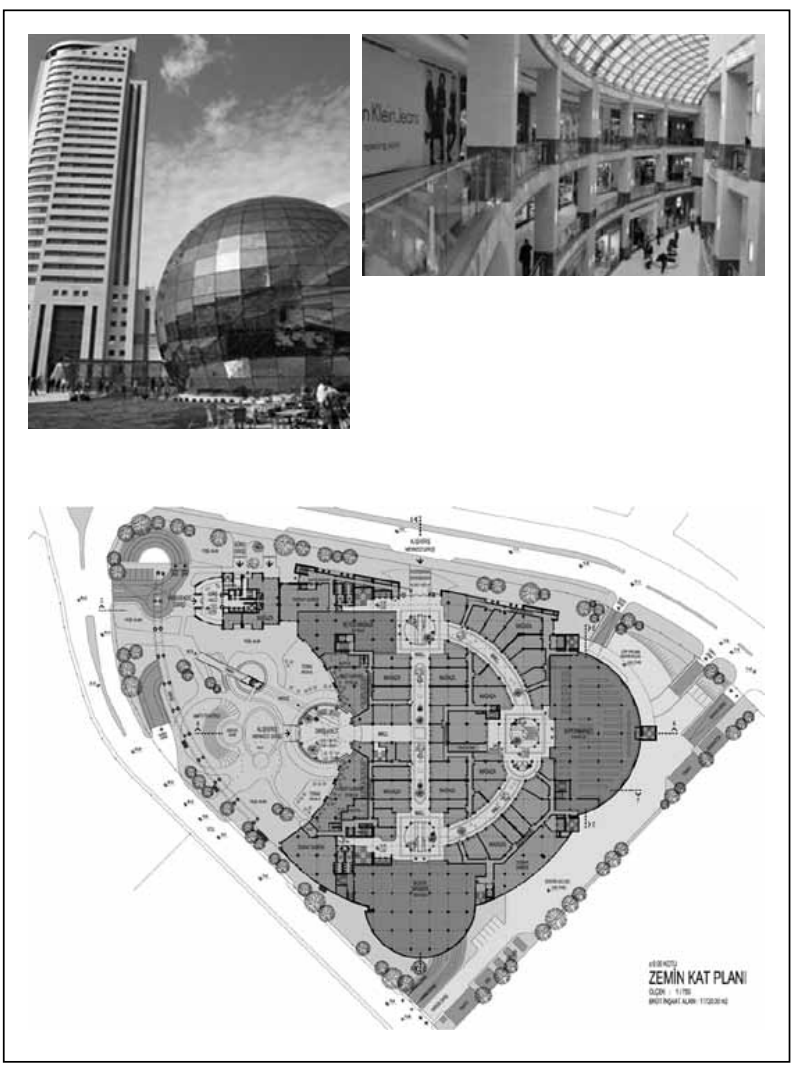

Fig. 7. Palladium Shopping Mall Plan-Exterior-Interior, Istanbul
Space organization. In terms of interior design, two separate shopping alleys were planned by giving prominence to qualities such as spaciousness, maximum utilization of daylight and ease of orientation. In the first alley where the emphasize is on horizontality, it was aimed to provide spatial spaciousness and to ensure that the shopping units arranged linearly at different elevations can be easily perceived from anywhere in the area. In the second alley, uninterrupted perception of the shopping units by the circulating visitors was achieved through an architectural skew designed in the plan. Contrary to these two shopping axes where continuous horizontal circulation is dominant, in the squares at the intersection points of the alleys, where visitors can give a short break to shopping, the emphasize is made on verticality with the contribution of the interior architecture and lighting (Arkiv 2013b).

Other functions included. The ground +32 floors residence block of the complex embodies 94 residences. All residences are directed towards the sea and the sun. A large part of the roof of the shopping mall block serves as an outdoor area for the social facilities that belong to the residences, and it is designed as a special socializing platform that features fitness center, swimming pool, green spaces and a running track (Arkiv 2013b).

\section{Buyaka}

Location. The project area (Fig. 2) is located on the developing and most significant artery of Istanbul. Although it is in the Anatolian side, due to its TEM connection it is considered as an extension of the European side and closer to the European side in consideration of the Ikitelli direction. The building complex was situated on a narrow and long field. The long edge of the field constitutes the impressive field of view of the project. Due to this reason, the design of the high and lengthy massive face that is perceived all along the long edge proved to be an important issue to be solved.

Special features. Contrary to the usual perception of shopping malls as massive function boxes, the starting point of the project design was to break and divide the monoblock effect. The same conceptual approach was also used to negate the monotony effect of multi-storey towers due to the mere repetition of floors. Masses of the building were segmented on the third dimension and positioned on top of each other. In this way, it was tried to offer a perception as the face of the building does not belong to a single structure, but multiple smaller structures (Arkiv 2013a). 


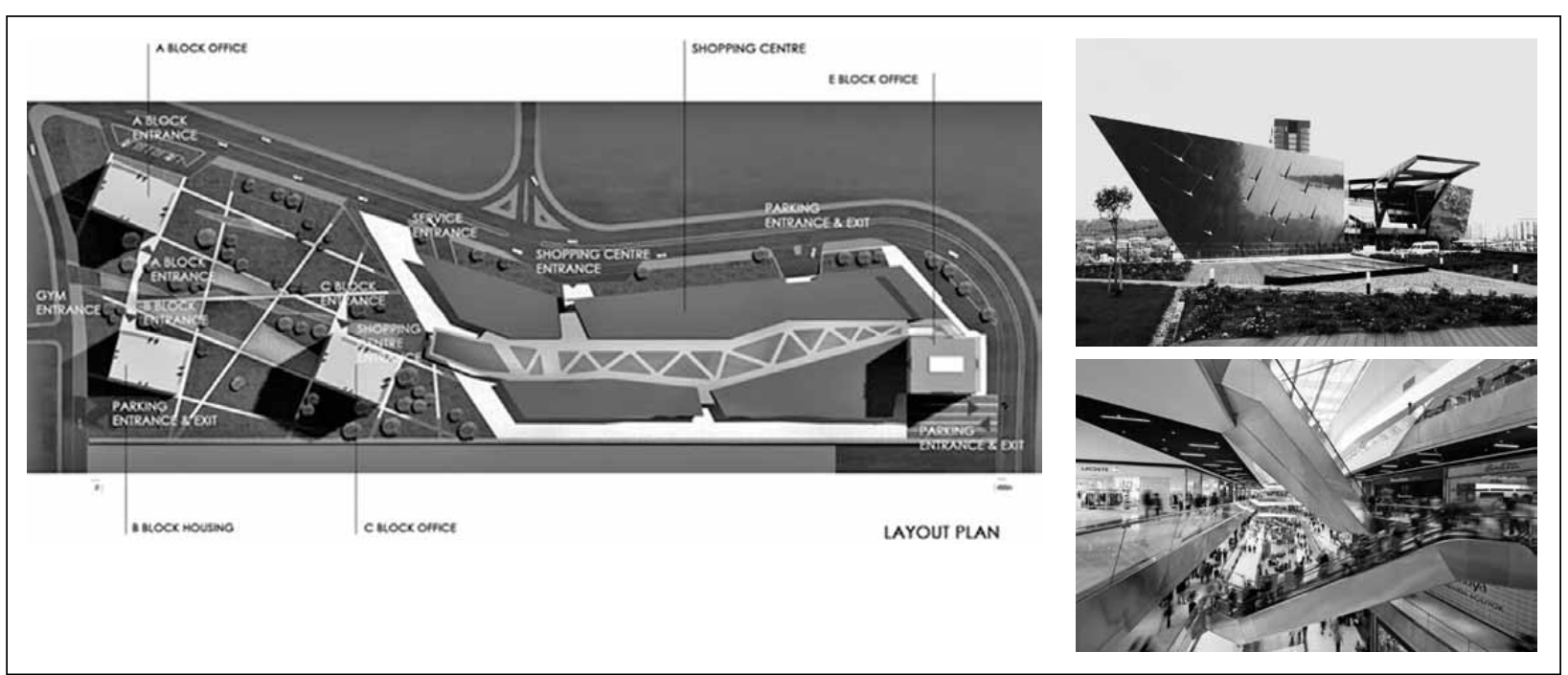

Fig. 8. Buyaka Shopping Mall Plan-Exterior-Interior, Istanbul

Space organization. In the design of the Buyaka shopping mall, interiors were interpreted as the internalization of the external. The external mass movements were developed into the interiors in line with the ideal insolation angle, and the aggressive and fluent external stance was addressed by providing continuity (Arkiv 2013a).

Other functions included. Described by its designers as a "group of multiple structures", Buyaka embodies two separate areas divided in terms of their use. The first area that is focused on commerce and business consists of a shopping center and an office block, while the second area covers sports and living areas. In between of the residence blocks, the roof of the sports area is planted and offers a wide recreational area (Fig. 8). The recreational area covers an approximate surface area of 18.000 square meters. The sports center with $13500 \mathrm{~m}^{2}$ indoor area was planned as a innovative facility with $2000 \mathrm{~m}^{2}$ area cardio and gym, a $2000 \mathrm{~m}^{2}$ spa and swimming pool, $2000 \mathrm{~m}^{2}$ locker rooms and courts for squash, basketball, beach volleyball and racquetball that sum up to $7500 \mathrm{~m}^{2}$. As for the office block, it was designed with a core structure developed on maximum use of area on storeys (Arkiv 2013a).

\section{Holistic assesment of examples}

In this section, the early and late period examples of Istanbul shopping malls that are examined within the scope of the study above were comparatively evaluated in the same terms with a holistic approach. While it is the relationship of the shopping malls with the city that is focused on under the topic of 'location', with the topic of "concept" it is rather the design philosophy that is considered. With the topic of 'space organization' the example malls were discussed in terms of their horizontal and vertical circulations (circulation axes) their differentiating spatial characteristics and the effects of these differences on the whole; and finally the examples were evaluated in terms of the other functions they feature (besides shopping).

Location. As it can be clearly seen also from the Istanbul-Shopping Mall collage (Fig. 2) all of the early period shopping mall examples included to the study were located in connection with either of the two most important axes of Istanbul's transportation networks, the TEM or E5 motorway. It was observed also from the collage that the late period examples have deviated from these axes and their locations were determined in line with the new/dense residential areas of Istanbul.

Special features. Although the shopping malls are all designed as closed indoor areas that are excluded from the outside, by means of either natural or artificial lighting, alley-like circulation axes and landscape design, the sense of being outdoors is tried to be proved (Kiliç, Aydoğan 2006). Most of time, it is the internal design that is prioritized rather than the external appearance of the main building that includes varying shopping units (Kiliç, Aydoğan 2006). The characteristics of real urban locations are superficially imitated within the building and it is aimed to recreate the complex and chaotic environment of the city in a sterile way (Birol 2005). According to Auge, venues that fail to be a "place" are deprived of the characteristics that define "place" such as variety, being surprising, uncertainty and livability (Birol 2005; Arefi 1999). One of the criticisms directed to shopping malls state that "... with their monotone designs they approach the place that includes the activity of shopping as an engineering project and they fail to respond to human needs such as 
belonging, collective identity, communication with the society and socialization as provided by the authentic places in traditional market places enriched with cultural accumulation" (Kiliç, Aydoğan 2006). Indeed, this building typology holds a global language of space in its essence and there is no place in that space for the familiarity of the local and the continuity of the traditional (Birol 2005; Yirtici, Uluoğlu 2004).

Imitation of some visual characteristics of the traditional city centers is common in new approaches of design. The use of some symbolic elements such as clock towers, fountains, etc. and association of the architectural characteristics of the region has become a part of the effort of shopping malls to gain an identity. Kiliç and Aydoğan define this effort as the "Simulation of Historic Bazaars and Buildings" (Kiliç, Aydoğan 2006).

Addition of some of the elements used in alleys, squares and outdoor arrangements into the design is a tendency that gains increasing popularity. With the use of urban landscape elements such as street furniture (street lamps, markings), planting, water elements, sculptures and plastic elements, outdoor designs are enriched visually (Kiliç, Aydoğan 2006). The developing process has rendered shopping malls serving to both the entertainment and social areas with movie theaters, restaurants, interactive playgrounds, children playgrounds and sports areas (McCloud 1999). The purpose is to ensure that a family can spend a whole day in such a center (Kiliç, Aydoğan 2006).

Space organization. Despite the fact that the number of the shopping malls increases rapidly, it was observed that the late period examples cover 3 or 4 times bigger areas than the early period examples (Table 1). Generally, in the plan scheme of shopping malls a linearly arranged circulation area that features at both ends reference or attraction points such as a large store, amusement center or food-courts is planned (Birol 2005). The circulation axes of the shopping malls examined within the scope of the study are presented in Table 1. Although no obvious difference between the early period and late period examples was observed, larger areas of use and higher level of vertical circulation and gathering points were found in late period examples in comparison with the early period examples. In late period examples the linear/forced horizontal circulation featured in the schemes of the early period examples were diversified and with references to the alleys and small squares in the city, alternative routes were provided. Examples of this alternative space setup can be seen in the below image, in store-alleys of IstinyePark and the 'sphere of infinity' in Palladium (Fig. 9).

Table 1. Shopping Malls (Early Period/Last Period)

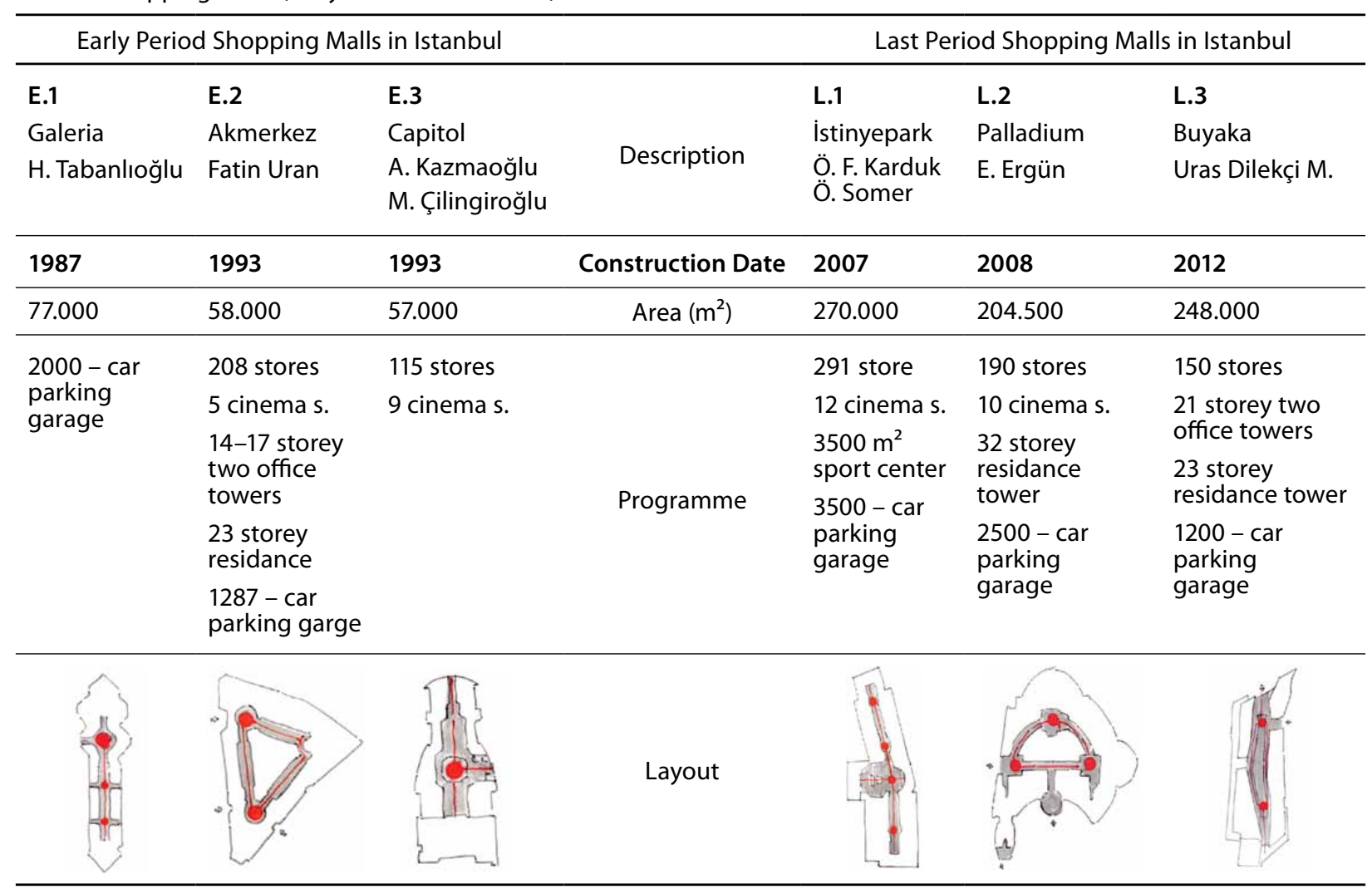

Source: authors. 


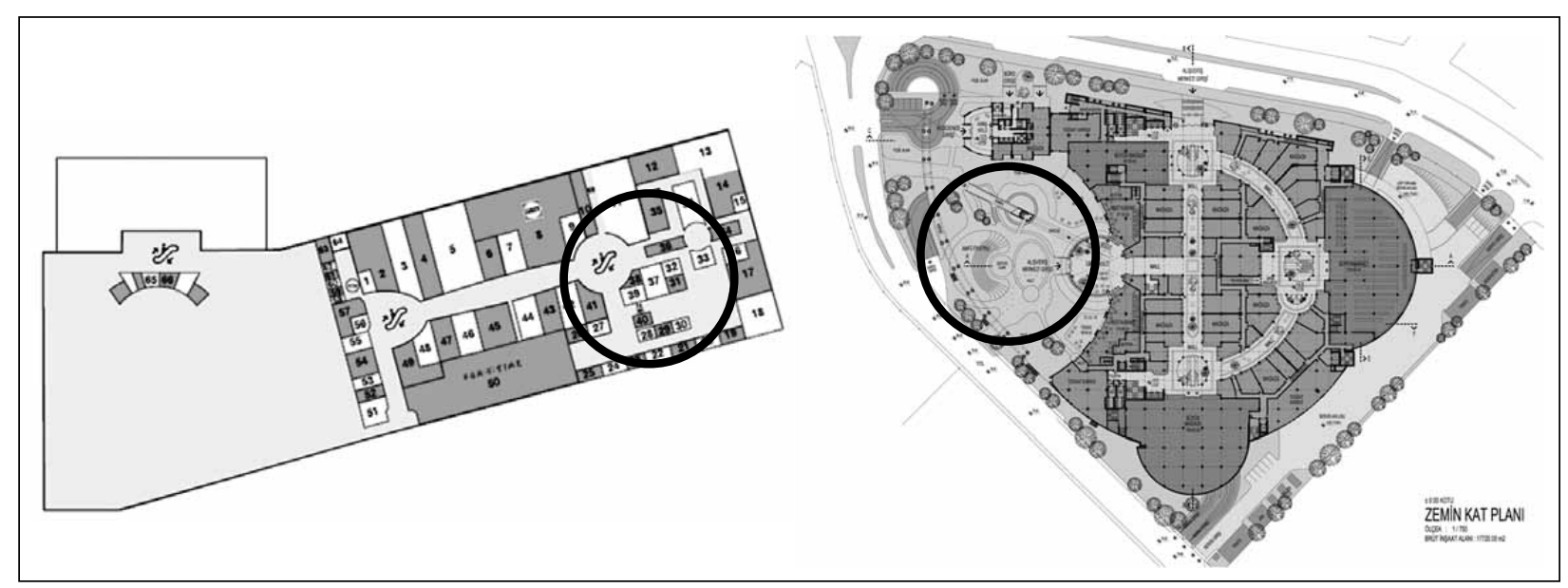

Fig. 9. Alternative circulation areas

Other functions included. It was observed that residence towers, featured only in Akmerkez among the early period examples, are featured in most of the late period examples. All malls feature varying functions besides shopping and among these cultural activities and gastronomy are prevalent. Many new functions were added to shopping (store) functions besides movie theaters (3500 square meters of wellness center in IstinyePark and 13500 square meters of sports center in Buyaka shopping mall), and both spatial variety and alternative uses were increased.

\section{Conclusions}

Having initially appeared from the idea of gathering shopping areas together in early 19th Century, shopping malls today are not places solely for shopping but with the addition of the functions such as entertainment, sports, residence and offices, they are presented as new life centers alternative to the city centers. Within the body of this group of building, a complex that includes many activities from entertainment to sports, from shopping to living was formed, and became the potential centers that provide all sorts of service possibility from baby care to commercial activities. With the addition of these functions, shopping malls became mix-use massive buildings and with their increasing number in Istanbul their significance and effect on the city increased, and permanently entered into the many domains from sociology to business, urban planning to architecture.

The attempt to revive some of the images that are present in the urban memory or the effort to utilize the state of being known-familiar in the 'new' has become an essential part of shopping malls. In a sense, it is possible to assert that the inclusion of the counterparts of urban venue components in the planning of shopping malls, in other words transformation of city squares into the wide gathering areas in shopping malls, streets and alleys into circulation axes, and reference points in cities into large stores or some attractive landscape elements (Lynch 1960) is due to this state of being known/familiar. The traces of this can be found in IstinyePark's approach that puts the theme of Market place on its center. Palladium shopping mall, on the other hand, tries to be irrelevant of time, and at the same time belonging to all times in its theme of infinity it added to its architectural quality with the sphere form. The architects of Buyaka shopping mall on the other hand, distinctly tried to achieve the space organization necessitated by the typology and that honestly centralizes the purpose of existence of shopping malls by rejecting all these labels or thematic approaches.

Although shopping malls were evaluated in terms of their spatial qualities within the scope of the present study, their places in the city and the relationship they establish or fail to establish with the city were also mentioned. The effect of shopping malls, the number of which constantly increases in Istanbul, on the city and its architecture is highly important. These massive bodies of buildings play a significant role in the formation and even definition of the new settlement areas of the city, and generate new areas of attraction. Due to these reasons, from location to architectural characteristic, from schedule to interior quality, they need to be designed punctiliously and with the consideration of the effects at all levels. When it is a metropolis such as Istanbul that is not only important for Turkey but all around the world and "embodies historic heritage and many sensitivities in terms of its geographical position" in question, these decisions bear vital importance. 


\section{References}

Arefi, M. 1999. Non-place and placelessness as narratives of loss: rethinking the notion of place, Journal of Urban Design 4(2): 179-193. http://dx.doi.org/10.1080/13574809908724445

Arkiv. 2013a. Buyaka [online], [cited 12 August 2013]. Available from Internet: http://v2.arkiv.com.tr/p7285-buyaka.html

Arkiv. 2013b. Palladium Alışveriş Merkezi ve Residence [online], [cited 12 August 2013]. Available from Internet: http:// v2.arkiv.com.tr/p9409-palladium-alisveris-merkezi-ve-residence.html

Arslan, T. V. 2009. Türkiye' deki Alışveriş Merkezleri İncelemelerine Eleștirel Bir Bakıș: Yorumlar, Eleștiriler, Tartışmalar, Uludăg Üniversitesi Mühendislik-Mimarlık Fakültesi Dergisi 14(1): 147-159.

Birol, G. 2005. Çağdaş Alışveriş Merkezlerinde Kent Dokusunun Yeniden Yorumlanması, Gazi Üniversitesi Müh. Mim. Fak. Dergisi 20(4) 421-427.

Dogru, H. 1995. XVIII Yüzyıla Kadar Osmanlı Kentlerinin Sosyal ve Ekonomik Görüntüsü. Anadolu Üniversitesi Yayınlar1, Eskisehir.

Dökmeci, V. 1995. Tüketimin Değişmesi ve Mega Çarşılar, Yapı Dergisi 158: 66-70.

Emiroglu, K. 2002. Gündelik Hayatımızın Tarihi. Dost Kitabevi, Ankara.

Harvey, D. 2013. Asi Şehirler. Istanbul: Metis Yayınları.

Güzel, O. N.; Sönmez, A. 2002. Alı̧̧veriş Merkezlerinin Yapısal Değişimi, Ege Mimarlık Dergisi 40-41, 41-45.

Kilıç, S. E.; Aydoğan, M. 2006. Alışveriş MerkezleriKent'İlişkisinde Kronikleşen Sorunlar, Toplu Ulaşım ve Yaya Ulaşımı İlişkileri: Forum (Bornova) Alışveriş Merkezi Örneği, Planlama 3: 89-95.

Lynch, K. 1960. The Image of the City. Cambridge: MIT Press.

McCloud, J. 1999. US Shopping centers thrive as hubs of entertainment, National Real Estate Investor, 41, 42-51.

Sayar, Y.; Süer, D. 2002. Alışveriş Merkezleri Türkiye Örnekleri, Ege Mimarlik Dergisi, 40-41, 14-19.

Tabanlığlu, H. 1989. Ataköy Turizm Merkezi, Turizm Tesislerinde Tasarım ve Uygulama, Tasarım Dergisi 3: 32-41.

Üstün, B.; Tutal, O. 2008. Tüketim Alışkanlıklarındaki Değişimler ve Bu Değişimlerin Alışveriş Mekanlarına Etkisinin Eskişehir Örneğinde İrdelenmesi, Anadolu University Journal Of Social Sciences 8(2): 259-282.

Yılmaz, E. 2002. Tüketim Peyzajları/Alışveriş Merkezleri, Ege Mimarlık Dergisi, 40-41, 20-22.

Yırtıcı, H.; Uluoğlu, B. 2004. Mekanın Altyapısal Dönüşümü, İTU Dergisi 3(1): 43-52.

\section{GULIZ OZORHON}

Faculty of Architecture and Design, Özyeğin University, Çekmeköy Campus Nişantepe District, Orman Street, 34794 Çekmeköy, Turkey.E-mail: guliz.ozorhon@ozyegin.edu.tr

Dr Güliz Özorhon, graduated from Yıldız Technical University, Faculty of Architecture in 2000. She obtained the master degree from Mimar Sinan University of Fine Arts. She completed her PhD studies at Yildız Technical University, Architectural Design Program by her thesis named "Housing Architecture of Istanbul in the Period of 1950-1960" between 2003-2009. She has studies published in several journals, presented in symposiums and congress and has awards in architectural design competitions. She is working as an Assistant Professor at the Faculty of Architecture and Design in Ozyegin University. Her recent research areas include Architectural Design, Spatial Organization, Sustainability, Ecological Design, Housing-Housing Settlements, Architectural Education.

\section{ILKER FATIH OZORHON}

Faculty of Architecture and Design, Özyeğin University, Çekmeköy Campus Nişantepe District, Orman Street, 34794 Çekmeköy, Turkey.E-mail: ilker.ozorhon@ozyegin.edu.tr

Dr İlker Fatih Özorhon graduated from Yıldız Technical University, Faculty of Architecture in 2000. He got the master degree from Istanbul Technical University by his thesis on "Natural Light with Its Aspect Determining the Identity of Architectural Space" at Architectural Design Program in 2002. He completed his PhD studies at Istanbul Technical University, Architectural Design Program by his thesis named "The Issue of Originality in Architecture: Turkish Modernity in the period of 1950-1960" in 2008. He has studies published in several journals, presented in symposiums and congress and has awards in architectural design competitions. He is working as an Assistant Professor at the Faculty of Architecture and Design in Ozyegin University. His recent research areas include Architectural Design, Design Teaching, Modernity and Modern Architecture, Modern Turkish Architecture. 